\title{
Are We Teaching What We Should? Re-Visiting Importance-Performance Analysis to Evaluate Tourism Studies Program
}

\author{
Dalia Zaki \\ Tourism Studies Department \\ Higher Institute of Tourism, Hotels and Computer, Alexandria
}

\begin{abstract}
Importance-Performance Analysis is a common technique that is used to understand customer satisfaction and service quality. As a method, it has been used effectively in education to close the loop between curriculum design, course feedback in class and graduate performance of learned tasks on the job. Using its' output helps to better understand the intended learning outcomes and related courses and thereby improve tourism studies program. This paper briefly revisits the IPA methodology integrated into Kirkpatrick's four-level framework of evaluation. A questionnaire survey was conducted among tourism studies graduates of the Higher Institute of Tourism and Hotels in Egypt in order to assess the degree to which learned knowledge or skills transferred to the actual job. The results demonstrated that data as a function of importance and performance allowed identification of working areas and those need further modification or rather removal. The implications derived by this study provide useful insights for enhancing programs of tourism studies in the Egyptian higher education.
\end{abstract}

Keywords: Higher Tourism Education, Program Evaluation, Learning Outcomes, Importance- Performance Analysis, Egypt

\section{Introduction}

The value of the nations not only relies on natural resources but it depends also on people, management and government. Education plays a basic role in the future of nations, and it is quite obvious that knowledge and education have effective roles in business environment; so that many organizations have identified the significant of strategy such as benchmarking to reach a competitive merit. ${ }^{1}$ In today's competitive environment, better performance and commitment to achieve a competitive advantage, ${ }^{2}$ is essential for education institutions as the places for knowledge worker, and education.

Nowadays, the number of institutions embracing Higher Tourism Education (HTE) has increased over the last 30 years. $^{3}$ Recently, they have come under increasing pressure to improve the quality and efficiency of the education services they provide, particularly as it relates to the preparation of graduates for the working environment. Institutions have long deliberated the issues of course content and design. ${ }^{4}$ However, a range of problems and issues have been highlighted. These include deficiencies in: ${ }^{5}$

- quality, as a result of rapid expansion,

- basic resources such as relevant textbooks and other reference materials,

- faculty members who have relevant qualifications and experience in the tourism field,

- government financial and other support, and

- tourism academic research.

On the other hand, after three decades of tourism development in Egypt, HTE in Egypt has expanded rapidly both in terms of number of institutions and enrolment of students. In such context, HTE entities have faced mounting criticism concerning the quality of their graduates, who have been considered behind the standard required by stakeholders. ${ }^{6}$

The purpose of this paper was evaluating the Tourism Studies Program to assess the degree to which learned knowledge or skills transferred to the actual job performance. It stimulated also further discussion and research on the validity and reliability of widely adopted Importance-Performance Analysis (IPA) technique and its appropriate applications, as it is in its current form, in HTE research. IPA as a tool has gained popularity among tourism and hospitality researchers for its simplicity and ease of application. Using its output helps to better understand the intended learning outcomes (ILOs) and related courses and thereby improve Tourism Studies Program. Also, this paper briefly revisits the IPA methodology integrated into Kirkpatrick's four-level framework of evaluation:

Level 1, Reaction, measures the graduate's perceptions of the course content, materials, and information presented in class. 
- Level 2, Learning, assesses the student's ability to demonstrate mastery of performance objectives in the learning environment.

- Level 3, Behavior, measures the graduate's 'on the job' application of learned knowledge or skills in the actual working environment.

- Level 4, Results, determines benefit to the organization. ${ }^{7}$

To carry out this research, the researcher focused only on Level 1 and 3 evaluations. The paper was divided into five parts of which this introduction was the first. Section two provided some background on the importance of evaluating HTE, IPA and it's applications in education. The methodology applied to the data was described in section three. The findings were illustrated on an IPA grid in section four, where discussion of these findings and possible extensions of the methodology were presented, while conclusions which could be drawn from the research were presented in the final section.

\section{Literature Review}

\section{The importance of evaluating HTE}

Evaluation of education and course quality in Higher Education Institutions (HEIs) has long been established both in the United States and Australia and they have become increasingly common in the United Kingdom. ${ }^{8}$ In a recent comparative review of course evaluation surveys in these countries, the Higher Education Academy stated that the importance of gaining systematic evaluations of courses by means of national surveys 'reflects the growing focus on the quality of teaching, formal institutional arrangements, and a growing emphasis on competition between higher education institutions'. ${ }^{9}$ Given the growing demand for skilled personnel at all levels in tourism and leisure industries, numbers of undergraduate tourism and leisure programs and enrolled students have expanded substantially. ${ }^{10}$ As knowledge has become a more critical resource, HEI is considered an important medium for flows of knowledge as well as people. ${ }^{11}$ However, knowledge and understanding is insufficient on its own to the development of a competent graduate. ${ }^{12}$ Hunter and colleagues added that graduates should have the skills to 'leverage the knowledge and understanding gained to interact, communicate and work effectively'. ${ }^{13}$ So many HEIs are now considering the graduate attributes necessary needed to enable them to be equipped and ready to work in a competent manner. ${ }^{14}$

Hence, evaluation is one of the strongest tools for strategic development in Higher Education (HE).$^{15}$ Such evaluation of various courses become necessity today, and is also the way to improve and increase quality of educational courses. ${ }^{16}$ Academics acknowledged the benefits of program evaluation to identify areas where student experience needs to be enhanced. HEI in the UK perform the annual program evaluation to provide opportunities for the program team to appraise its performance in achieving its objectives. ${ }^{17}$ The contribution of graduates to the success of HEIs is a key feature in some countries among which UK institutions are being encouraged to pursue these network ties as long-term benefactors and supporters of their work. Ensuring that programs of study are relevant to industry and society is a prevalent part of the HE. ${ }^{18}$ Accordingly, within Egypt, there should be an upsurge of interest in evaluating HTE from a range of different perspectives driven both internally by institutions themselves and externally by National Authority for Quality Assurance and Accreditation of Education (NAQAAE) for increased accountability and quality assurance. In particular, the issue of assessing the compliance of the individual courses in a program with the competencies assigned to the program.$^{19}$ Given that course design is one of the determining components in the quality assurance perspective, ${ }^{20}$ the results of this assessment are to be used to improve program quality. ${ }^{21}$

\section{Applications of IPA in Education}

IPA is a common technique that is used to understand customer satisfaction and service quality. ${ }^{22}$ Hospitality and tourism research has drawn extensively on it to monitor services such as hotels, restaurants and tours. IPA could provide an insight into customers' evaluations on critical issues in the tourism industry. ${ }^{23}$ As an evaluation tool, it graphically depicts the gap between a current perceived state or condition and a future expected outcome. ${ }^{24} \mathrm{Nale}$ and colleagues suggested that researches directed to improving HE outcomes have a drawback: they focus exclusively either on importance or on performance. ${ }^{25}$ To alleviate this concern, the two factors can be combined. ${ }^{26}$ Thus, IPA could be used effectively in educational institutions. ${ }^{27}$ Using the same techniques to measure the gaps between the perceived importance of an attribute and how 'good' (performance) the attribute is perceived to be by a customer (i.e. graduate). Each attribute will fall into one of four quadrants defined by Ortinau and colleagues. ${ }^{28}$

- Data landing in the upper right quadrant (high importance/high performance), defined as 'Keep Up The Good Work,' suggests that the current conditions and expected outcomes are being met and these are strengths.

- Conversely, the upper left quadrant (high importance/low performance) is identified as 'Concentrate Here'. Data in this quadrant indicate importance outweighs ability, and these attributes present opportunities for corrective action. 
- The lower right and left quadrants (low importance/high performance and low importance/low performance), labeled 'Possible Overkill' and 'Low Priority', suggest that the attribute may be superfluous due to low importance so these attributes may be candidates for discontinuation.

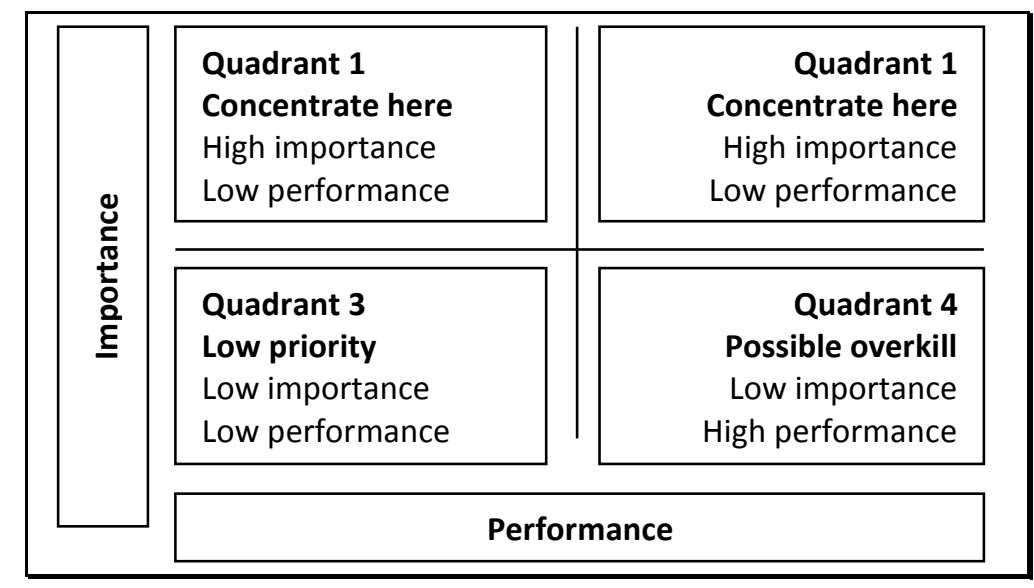

Figure 1: Importance and Performance Analysis Grid, Source: O'Leary and Deegan . ${ }^{29}$

Siniscalchi and colleagues adapted the IPA approach to continue these efforts by using it as a method to close the loop between curriculum design, instructor/course feedback in class and graduate performance of learned tasks on the job. ${ }^{30}$ The current research used their work as a platform, adopted and modified their IPA approach. However, the present investigation was not intended to be a replication. The former work was based upon a sample of trainees for a training institute, versus tourism studies graduates here. More importantly, the specific objective of their research was to improve leadership training by using the IPA output to help better understand of instructors and instruction. A facet decidedly irrelevant to the current research that is hitting the learning outcomes effectively and thereby improving curriculum.

\section{Research Methodology}

\section{Case Study}

Since 1962, HTE started in Egypt. In 1968 a high institute for tourism and another one for hotels were established admitting university and institutes graduates. In 1975 the two institutes merged and the faculty of Tourism and Hotels, Helwan University was founded. Lately, eight governmental universities provide tourism education. This is in addition to two private universities, four technological faculties, and 16 private high institutions. ${ }^{31}$ Also, the Higher Institute of Tourism, Hotels and Computer (HITHC) is one of the private High Institutions that has been established by the Minister's Provisions and according to Act of Law No.52 in 1970 of organizing private high education as well as its executive annex No.1088 in 1987. Dated back to 1992, the institute has been since supervised by the Ministry of High Education, ${ }^{32}$ with an average throughput of 75 graduates annually. All High Tourism Institutions in Egypt provide the same program with almost the same ILOs guided by the Academic Standards for the Tourism and Hotels Sector issued by NAQAAE. ${ }^{33}$ Thus, the tourism program in HITHC is completed in four years, offering 41 courses, in addition, to 'Human Rights' course which has been added to all the academic programs in Egypt since 2005 (Table 1). It was proposed that the graduates should develop the following ILOs:

\section{A. Knowledge and understanding}

\section{Graduate must be able to:}

A.1. Recognize the concepts, theories and economic principles within the tourism industry.

A.2. Explain the functions of marketing and its applications in tourism.

A.3. list the various uses of information technology applications in tourism activities.

A.4. Identify the most important terms of tourism in different languages.

A.5. State the basis of planning, its applications and its impact in the field of tourism.

A.6. Illustrate the basis of cost accounting for tourism projects.

A.7. Recognize the working nature of the travel agencies, tourism organizations and tourist transport companies.

A.8. Explain the role of communication, public relations and tourism media and its impact on tourism activity.

A.9. Recognize the principles and rules of administrative and legislative framework for tourist facilities.

A.10. Identify the principals of tourism development and the most important constraints in accordance with domestic and international variables.

A.11. Recognize the history of ancient Egypt and archaeological sites.

A.12. Recognize the modern trends in tourism.

A.13. Explain the role of the environment and its impact on tourism planning and tourist activity. 
A.14. Explain the administrative and marketing decisions in the tourism sector in the light of the rules governing tourism activity as determined by the local and international tourism organizations.

A.15. Apply scientific methodology, data collection tools and statistical analysis in the analysis of problems.

A.16. Apply basis of feasibility studies on tourism projects.

A.17. Recognize the principles and rules of public health, security and occupational safety.

\section{B. Intellectual skills}

Graduate must be able to :

B.1. Assess the economic feasibility studies for various tourism projects.

B.2. Present proposals to reduce the economic and environmental problems related to tourism in Egypt

B.3. Analyze the components of economic activity in the different sectors of tourism in Egypt.

B.4. Analyze the data using the tools and appropriate statistical methods in tourism projects.

B.5. Link theoretical concepts and practical applications to keep pace with the development in the field of tourism.

B.6. Select the most appropriate procedures, arrangements and linguistic forms for customer service in the travel agencies.

B.7. Link the characteristics of tourist destinations with the tourism industry.

B.8. Analyze the relationship between tourism planning and the environment preservations and its impact on the tourism industry.

B.9. Invent new methods for tourism promotion and tourism marketing for tourist destinations in Egypt

B.10. Apply new trends in tourism for developing tourism industry and reinforcing the concept of sustainability.

\section{Professional skills}

\section{Graduate must be able to :}

C.1. Prepare tourism programs and issue airline tickets according to customer needs and international standards.

C.2. Prepare cost reports, budgets and audit and performance reports.

C.3. Prepare feasibility study for a tourism project.

C.4. Prepare tourism marketing plans for the various tourist services.

C.5. Deal efficiently with different procedures of transactions in travel agencies.

C.6. Use bulletins, brochures and publications of international organizations in tourist activity.

C.7. Propose innovative methods to strengthen the modern trends of tourism in Egypt.

C.8. Employ his knowledge in performing the functions of customer service and problems solving in a professional manner taking into consideration the different cultures and languages.

C.9. Use proper grammar in customer service and deals with various sample of communication used in the profession.

C.10. Use computer systems, software applications and programs specialized in the field of tourism.

\section{General skills}

Graduate must be able to :

D.1. Use information technology (computer and internet).

D.2. Participate in a positive teamwork.

D.3. Practice effective communication in a multicultural environment

D.4. Manage time and deals with the pressures of work.

D.5. Practice self-learning activities.

D.6. Use scientific methodology in planning and problem solving.

Table 1: Tourism Studies Courses

\begin{tabular}{|l|l|}
\hline Courses & Courses \\
\hline 1. Introduction To Tourism Science & 18.Travel Agencies(1) and (2) \\
\hline 2. Principles Of Hospitality Industry & 19.Tourism Authorities And Organization \\
\hline 3. Ancient Egyptian History And Archaeological Sites & 20.Tourism And Hotels Legislation \\
\hline 4. Principles Of Economics & 21.Tourism Economics \\
\hline 5. Tourism Geography & 22.New Trends In Tourism \\
\hline 6. Egyptian Environment & 23.Tourism And Environment \\
\hline 7. Public Health & 24.Tourism Sales Development \\
\hline 8. Principles Of Management & 25.Airlines (1) and (2) \\
\hline 9. First Language (1), (2), (3) and (4) & 26.Tourism Planning \\
\hline 10. Second Language (1), (2), (3) and (4) & 27.Feasibility Study \\
\hline 11. Computer & 28.Tourism Development \\
\hline 12. Principles Of Accounting & 29.Tourism Transportation Economics \\
\hline 13. Principles Of Statistics & 30.Tourism Marketing \\
\hline 14. Travel Agencies Management & 31.Tourism Media \\
\hline 15. Domestic And International Tourism & 32.Tourism Correspondences \\
\hline 16. Travel Agencies Accounting & 33.Tourism Project \\
\hline 17. Tourism Statistics & \\
\hline Source. www seyouforg 34 & \\
\hline
\end{tabular}

Source: www.seyouf.org. ${ }^{34}$ 


\section{Research Instrument}

Two levels were considered in the context of HTE evaluation. Level 1; evaluations were used to measure a graduate's reaction to the course material and the information presented in class. To make this comparison, the researcher had adjusted the IPA axes to relate course content (importance) to information presented (performance). Specifically, the graduate was asked to rate the importance of each course content on a 5 - point scale; from $1=$ not important at all to $5=$ very important, then evaluate to what extent the information presented in the course material is useful to perform a job on a 5- point scale; from $1=$ very useful to $5=$ not useful at all. The original quadrant labels were appropriate (from upper right, anti clockwise) 'keep up the good work', 'concentrate here', 'low priority' and 'possible overkill' (Figure 2).

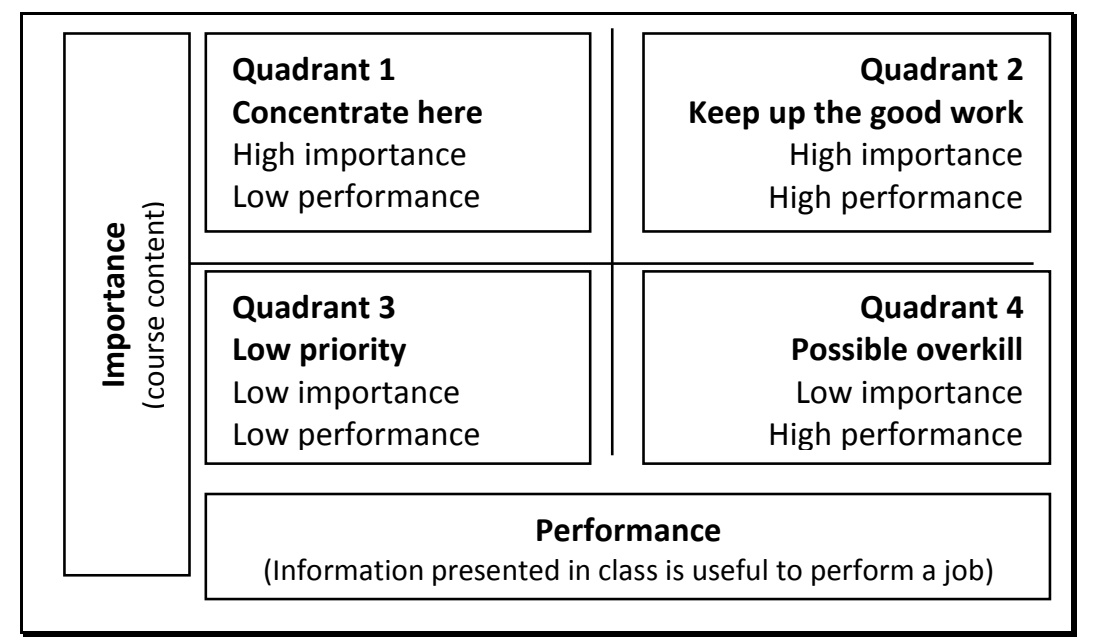

Figure 2: Level 1- Reaction evaluation IPA grid Source: adapted from Siniscalchi et al. ${ }^{35}$

Level 2; incorporating behavior evaluation with IPA was a straightforward way to help compare graduate performance ability to an important ILOs, defined in program. For each ILO, the graduate was asked to rate how important this ILO is to the overall job on a 5- point scale; from $1=$ not important at all to $5=$ very important, then evaluate their ability to perform the job task on a 5 - point scale; from $1=$ poor ability to $5=$ expert ability. The assessment of importance and the graduates' perception of performance (based on what they learned in class) was plotted to form the IPA matrix (Figure 3).

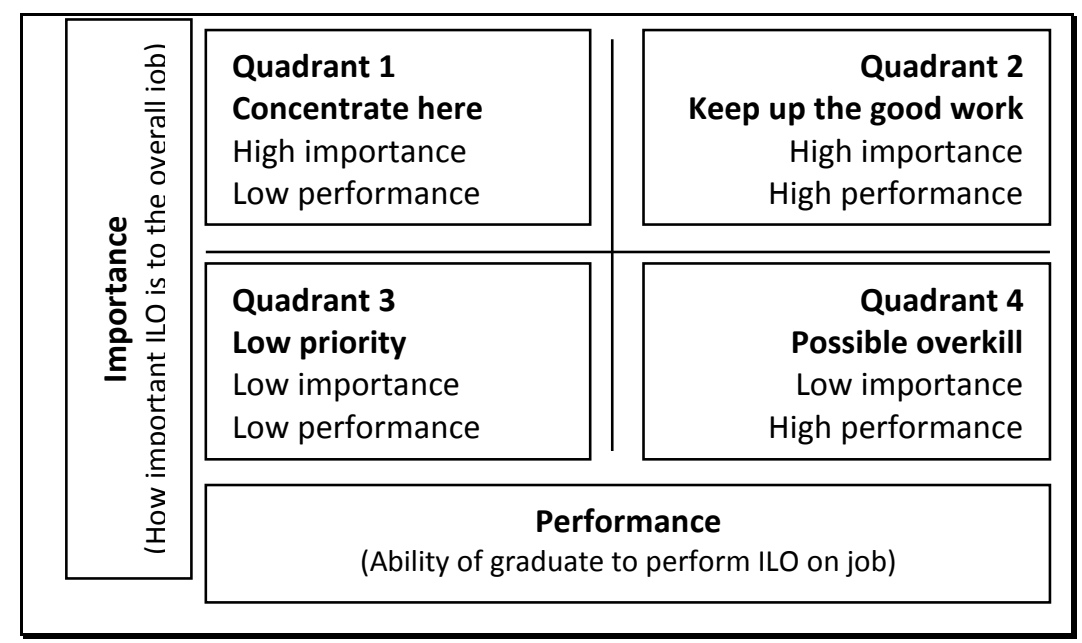

Figure 3: Level 2- Behavior evaluation IPA grid Source: adapted from Siniscalchi et al. ${ }^{36}$

To carry on with this evaluation a questionnaire survey was conducted during the period between April and June 2014. The questionnaire constituted of closed- ended questions and was formed of three sections. Section one; was designed to collect information related to personal identification and education. Section two; consisted of 41 courses titles (Table 1) and section three comprised 43 ILOs divided into four categories to analyze knowledge and understanding, intellectual skills, professional skills and general skills. The questionnaire was first written in English language and then was translated into Arabic language (to make it easier to be understood by the target population). 


\section{Sampling}

Information about employed tourism studies graduates in the field was very difficult to gather. So, snowball sampling was used to create an expanding chain of referrals, ${ }^{37}$ to inform the researcher about possible individuals. Snowball sampling techniques have certain limitations as they are inclined towards the selection of individuals on the basis of networks. ${ }^{38}$ However, when a population is unknown and there is little information available about it, snowball sampling can provide a better understanding and more complete characterization of a population. ${ }^{39}$ The researcher identified a few individuals that she knew and then relied on them to help to identify more individuals. This process continued until all contacts have been exhausted. Through this approach, a total of 74 surveys were gathered, all found to be eligible for analysis.

\section{Data Analysis}

The data was analyzed by calculating frequency, mean and standard deviation. Mean scores rating importance and performance of the attributes were computed to access the importance of each item respectively. Then, the mean scores of each item were plotted on the IPA grid according to their importance and performance as perceived by the graduates. Referring to the questionnaire proposed; items were acquired with the Cronbach's alpha, reliability values being ranged from 0.79 to 0.842 . The questionnaire was further proceeded Factor Analysis which demonstrated that the factor loadings were exceeding 0.52. Consequently, the questionnaire had considerable reliability and good construct validity. ${ }^{40}$

\section{Findings}

\section{Personal Identification and Education Information}

Overall, the respondents were $82.4 \%$ male and $17.6 \%$ female, $70.3 \%$ were within the $21-24$ years age bracket, while $29.7 \%$ were between 25 and 29 years. Almost half of the respondent (48.6\%) had been working in the field for less than one year, $28.4 \%$ have been working for two years and $23 \%$ had experience in the field for three years. Most of the respondents $(85.1 \%)$ agreed that tourism studies must be completed in four years and almost half of the respondents $(41.9 \%)$ agreed that majoring in tourism studies should be from first year, $36.5 \%$ stated that it should be from second year and $21.6 \%$ stated that majoring in tourism studies should be from third year. The completed breakdown of respondents' personal identification is provided in Table 2.

Table 2: Summary of respondent personal identification

\begin{tabular}{|l|c|c|}
\hline & Frequency & Percent \\
\hline Gender & & \\
\hline Female & 13 & 17.6 \\
\hline Male & 61 & 82.4 \\
\hline Age & & \\
\hline $21-24$ years & 52 & 70.3 \\
\hline $25-29$ years & 22 & 29.7 \\
\hline $30-34$ years & 0 & 0 \\
\hline 35 years or more & 0 & 0 \\
\hline Years of experience in the field & & \\
\hline Less than 1 year & 36 & 48.6 \\
\hline 2 years & 21 & 28.4 \\
\hline 3 years & 17 & 23.0 \\
\hline 4 years or more & 0 & 0 \\
\hline Tourism studies needs to be completed in & & \\
\hline 1 year & 0 & 0 \\
\hline 2 years & 0 & 0 \\
\hline 3 years & 63 & 11 \\
\hline 4 years & & 85.1 \\
\hline Majoring in tourism studies needs to be from & 31 & 41.9 \\
\hline First year & 16 & 36.5 \\
\hline Second year & & \\
\hline Third year & & \\
\hline
\end{tabular}

\section{Level 1- Courses evaluation IPA grid (Reaction)}

The mean scores (M) and standard deviations (S.D.) of the perceived importance and performance of the 41 courses titles were calculated. The mean scores for importance and performance were then plotted on the IPA grid (Figure 4). Eight courses were identified in the upper right quadrant 'Keep Up The Good Work' as they were perceived high importance and performance. The courses titles as perceived respectively; Second Language (1), (2), (3) and (4), Computer, Tourism Planning, Tourism Media, Tourism Authorities And Organization, Domestic And International 
Tourism, Airlines (1) and (2), and First Language (1), (2), (3) and (4). Hence, the findings suggested that the current conditions and expected outcomes were being met and these were strengths.

Conversely, the upper left quadrant 'Concentrate Here' identified also eight courses titles as they were rated as high importance and low performance. The courses titles as perceived respectively; Ancient Egyptian History and Archaeological Sites, Introduction To Tourism Science, Tourism And Hotels Legislation, Tourism Project, Tourism Development, Travel Agencies (1) and (2), New Trends In Tourism, and Tourism Marketing. Data in this quadrant indicated importance outweighs ability, so these courses presented opportunities for corrective action.

The lower left quadrant 'Low Priority' captured eight courses tittles that were rated low in both importance and performance. The courses titles as perceived respectively; Tourism Statistics, Travel Agencies Management, Principles of Management, Tourism Geography, Tourism Economics, Public Health, Principles of Statistics, and Tourism Sales Development. While, nine courses titles went in the lower right quadrant labeled 'Possible Overkill' as they were perceived with low importance and high performance. The courses titles as perceived respectively; Principles of Hospitality Industry, Egyptian Environment, Feasibility Study, Principles Of Economics, Tourism Transportation Economics, Travel Agencies Accounting, Tourism And Environment, Tourism Correspondences, and Principles Of Accounting. The findings suggested that these courses might be superfluous due to low importance so these courses might be candidate for discontinuation.

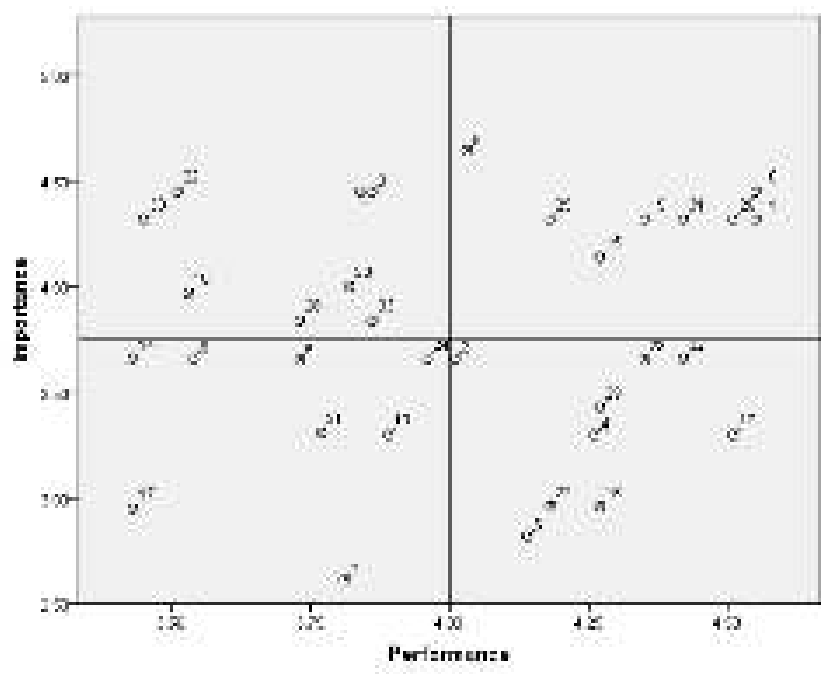

Figure 4: Level 1 - Courses evaluation IPA grid

\section{Level 2- ILOs evaluation IPA grid (Behavior)}

The mean scores (M) and standard deviations (S.D.) of the perceived importance and performance of the 43 ILOs were calculated. The mean scores for importance and performance were then plotted on the IPA grid. Four grids were formed to demonstrate the four categories of ILOs that is; knowledge and understanding, intellectual skills, professional skills and general skills.

The results were used to form the IPA grid of 'Knowledge and Understanding'. As shown in Figure (5), six ILOs were identified in the 'Keep Up the Good Work' quadrant. The ILOs as perceived respectively; Recognize the working nature of the travel agencies, tourism organizations and tourist transport companies, Recognize the history of ancient Egypt and archaeological sites, Illustrate the basis of cost accounting for tourism projects, Identify the principals of tourism development and the most important constraints in accordance with domestic and international variables, Explain the functions of marketing and its applications in tourism, and State the basis of planning, its applications and its impact in the field of tourism. These ILOs were rated above average for both importance and performance. These results conveyed the message that in general, tourism studies program had performed well in the above respects.

In the 'Concentrate Here' quadrant five ILOs were rated above average for importance but below average on performance. The ILOs as perceived respectively; Recognize the modern trends in tourism, Explain the role of communication, public relations and tourism media and its impact on tourism activity, Identify the most important terms of tourism in different languages, Recognize the concepts, theories and economic principles within the tourism industry, and list the various uses of information technology applications in tourism activities. Efforts and special attention should be directed at and concentrated on these ILOs.

There were six ILOs allocated in the 'Possible Overkill' quadrant. This indicated that the ILOs were rated as lower than the average of importance and that the performance on this area was higher than the average. The ILOs as perceived respectively; Explain the role of the environment and its impact on tourism planning and tourist activity, Apply basis of feasibility studies on tourism projects, Explain the administrative and marketing decisions in the tourism 
sector in the light of the rules governing tourism activity as determined by the local and international tourism organizations, Apply scientific methodology, data collection tools and statistical analysis in the analysis of problems, Recognize the principles and rules of administrative and legislative framework for tourist facilities, and Recognize the principles and rules of public health, security and occupational safety. In fact, respondents considered these ILOs as less important compared with other ILOs and all efforts are wasted and could be employed elsewhere.

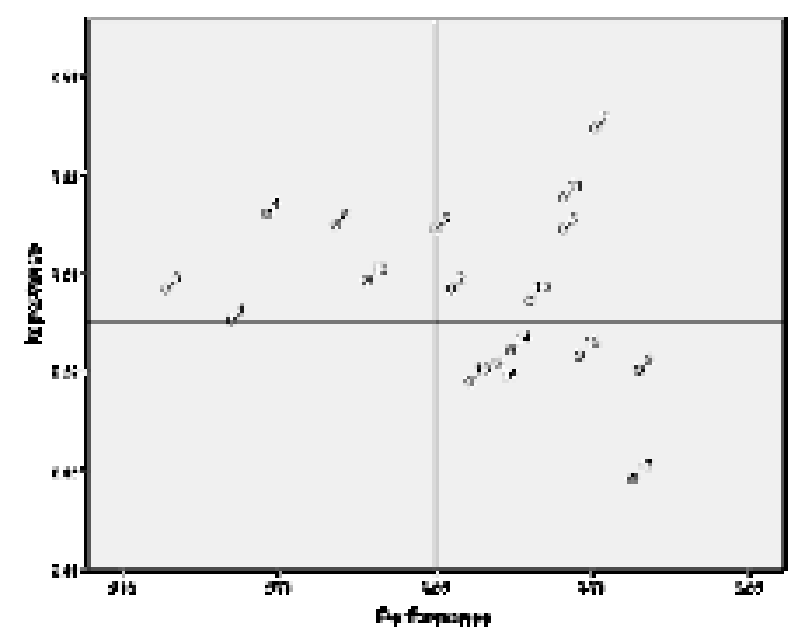

Figure 5: Level 2- Knowledge and Understanding evaluation IPA grid

Following the same previous procedure to form the IPA grids of the three other ILOs categories. The mean scores for importance and performance of 'Intellectual Skills' were plotted on the IPA grid (Figure 6). Four ILOs were identified in the 'Keep up the Good Work' quadrant. The ILOs as perceived respectively; Select the most appropriate procedures, arrangements and linguistic forms for customer service in the travel agencies, Link theoretical concepts and practical applications to keep pace with the development in the field of tourism, Link the characteristics of tourist destinations with the tourism industry, and Analyze the data using the tools and appropriate statistical methods in tourism projects.

The 'Concentrate Here' quadrant captured two ILOs. The ILOs as perceived respectively; Present proposals to reduce the economic and environmental problems related to tourism in Egypt, and Analyze the components of economic activity in the different sectors of tourism in Egypt. Three ILOs were in the 'Low Priority' quadrant. The ILOs as perceived respectively; Invent new methods for tourism promotion and tourism marketing for tourist destinations in Egypt, Analyze the relationship between tourism planning and the environment preservations and its impact on the tourism industry, and Assess the economic feasibility studies for various tourism projects. While, Apply new trends in tourism for developing tourism industry and reinforcing the concept of sustainability went in the 'Possible Overkill' quadrant.

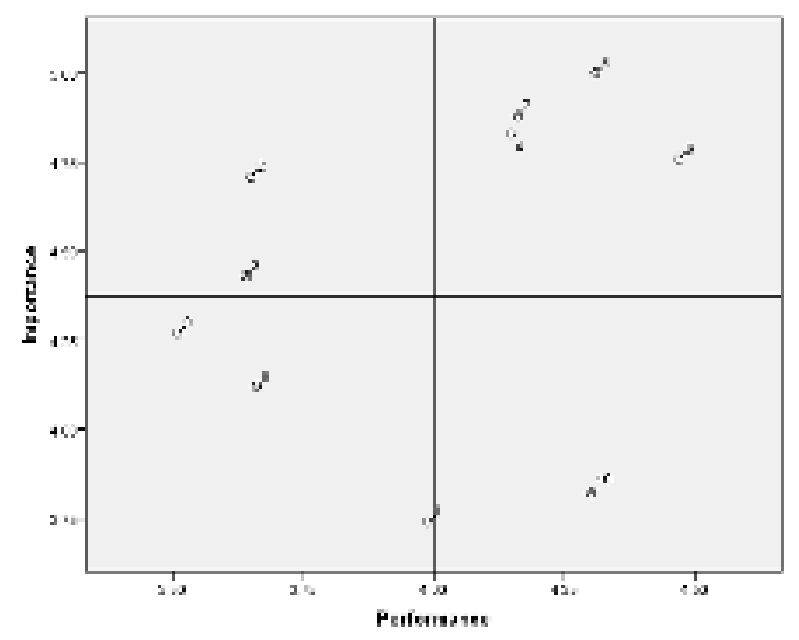

Figure 6: Level 2- Intellectual Skills evaluation IPA grid

Respectively, the mean scores for importance and performance of 'Professional Skills' were plotted also on the IPA grid (Figure 7). Four ILOs were allocated in the 'Keep up the Good Work' quadrant. The ILOs as perceived respectively; Deal efficiently with different procedures of transactions in travel agencies, Prepare cost reports, budgets and audit and performance reports, Prepare feasibility study for a tourism project, and Prepare tourism marketing plans 
for the various tourist services. While, two ILOs were identified in the 'Concentrate Here' quadrant. The ILOs as perceived respectively; Employ his knowledge in performing the functions of customer service and problems solving in a professional manner taking into consideration the different cultures and languages, and Prepare tourism programs and issue airline tickets according to customer needs and international standards. Another two ILOs were identified also in the 'Low Priority' quadrant. The ILOs as perceived respectively; Use computer systems, software applications and programs specialized in the field of tourism, and Use proper grammar in customer service and deals with various sample of communication used in the profession. Finally, two ILOs were plotted in the 'Possible Overkill' quadrant. The ILOs as perceived respectively; Use bulletins, brochures and publications of international organizations in tourist activity, and Propose innovative methods to strengthen the modern trends of tourism in Egypt.

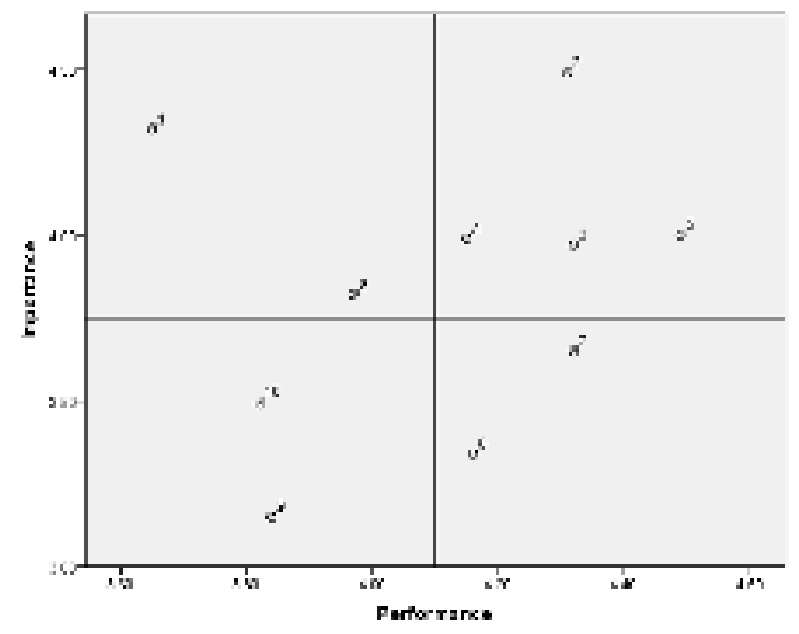

Figure 7: Level 2- Professional Skills evaluation IPA grid

Finally, the mean scores for importance and performance of the 'General Skills' were plotted also on the IPA grid (Figure 8). Two ILOs were captured in the 'Keep up the Good Work' quadrant. The ILOs as perceived respectively; Use information technology (computer and internet), and Participate in a positive teamwork. Three ILOs were identified in the 'Concentrate Here' quadrant. The ILOs as perceived respectively; Practice self-learning activities, Use scientific methodology in planning and problem solving, and Practice effective communication in a multicultural environment. While, Manage time and deals with the pressures of work went in the 'Possible Overkill' quadrant.

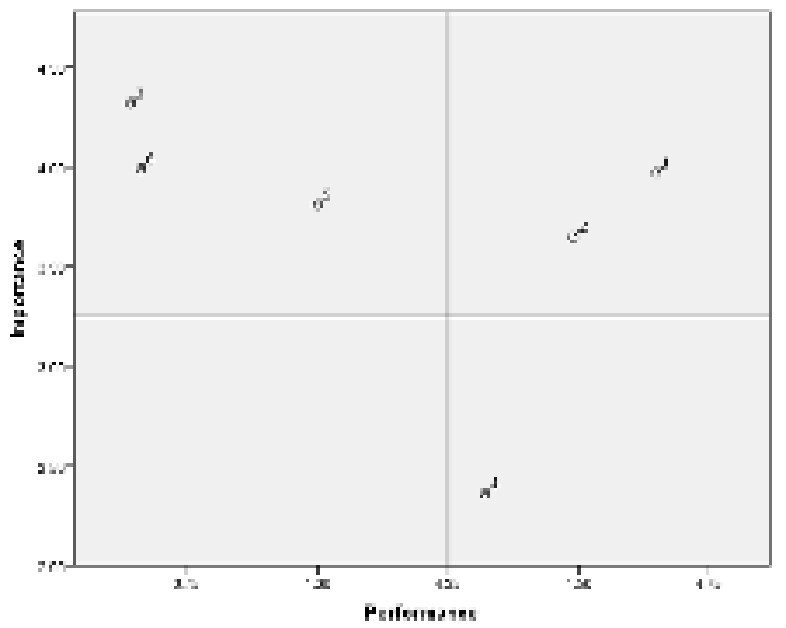

Figure 8: Level 2- General skills evaluation IPA grid

\section{Conclusion}

This paper evaluated Tourism Studies Program to assess the degree to which learned knowledge or skills were transferred to the actual job performance. Apparently, some striking results were found. The IPA output could be used to facilitate improvement in areas of concern. It could not only help by indicating areas of teaching 'hitting the mark' but also help modifying a curriculum, so that future graduates could master outcomes directly applicable to their job performance. The findings successfully served to close the loop in the curriculum design and course content and graduate performance of learned tasks on the job. Plotting level 1 data as a function of importance and performance allowed identification of valuable courses, such as; Languages, and Computer as well as courses that might need further revision or removal, such as, Ancient Egyptian History and Archaeological Sites, or Principles Of Hospitality Industry. 
HTE might be mandated by regulation, as is often the case with Academic Standards for the Tourism and Hotels Sector issued by NAQAAE. However, in the absence of obligatory requirement, the data have given authority to the decision to remove the course from the program.

Accordingly, those ILOs that plotted low either on the importance axis or on the performance axis or both (low priority and possible overkill quadrants) were likely to need the most review. For example, assessing the economic feasibility studies for various tourism projects (Intellectual Skills) revealed that the graduates had a high level of skill on the job but this skill found to be not important. Conversely, the ILOs plotted as extremely important to the job, but the graduates had a low level of skill completing the task (concentrate here quadrant), for example, prepare tourism programs and issue airline tickets according to customer needs and international standards (Professional Skills). The data have revealed a starting point for additional inquiry. Graduates skill found to be low either because the course content is inadequate or students had not enough opportunities to practice. Each reason would lead to a different corrective approach in the revised curriculum.

Keeping in mind that the data indicated particular areas in the program that should not be changed-as evident by ILOs plotting high in both importance and performance (keep up the good work quadrant)- such as recognize the working nature of the travel agencies, tourism organizations and tourist transport companies (Knowledge and Understanding). This paper presented useful insights on learned knowledge or skills that were actually transferred to the job performance in order to meet the requirements of the tourism industry. However, graduates made use of only 25 percent of the courses taught that focus mainly on languages (eight courses) and computer discarding more courses titles covering issues related to tourism industry and its technology. Graduates were overwhelmed with 17 basic and general courses that have nothing to do with the pursuit of their career. Respectively, the courses taught needed to be revised in accordance with the real needs in the workplaces and must include some practical courses covering titles such as; business etiquette, communication and customer service.

In addition, graduates acquired only $37 \%$ of the skills that must be developed through four years of tourism studies education (35\% of knowledge and understanding, $40 \%$ of intellectual skills, $40 \%$ of professional skills and $33 \%$ of general skills). This could justify the continuous complaining from the industry about graduates' performance. Adjustment must be done to the ILOs especially those Intellectual Skills and Professional Skills to enhance graduates competencies in critical thinking, dealing with diversity, and problem solving for example.

Some limitations of this research should be noted which can be a base for future research areas. The major limitation rested in the sampling. The convenience sample could not claim to be representative, in order to enhance the findings, a survey on a larger sample should be conducted. A major challenge in tourism studies higher education was not taken into account in this research; the diversity of the background of academics and the ways in which they teach could shape the curriculum, so a comparison of teaching styles and educational background of teaching staff could be conducted. It must be noted here also that some of the ILOs analysis showed some contradictions with the courses analysis; which might be due to the complete incomprehensibility of the graduates to such ILOs. This indicated that the ILOs have not been explained to the graduates during their academic years. This study was carried out at HITHC, It is then suggested that further research on other institutions need to be done for the reason of better understanding and comparison. Comparable research could be done in order to examine whether there is any difference between tourism graduates who studied in different institutions. Future researchers may conduct also in-depth research in analyzing the views of tourism industry, academic staff and practitioners. It could be realized that, some of the new innovated competencies could only be developed through high quality monitored industry internship program, so more close industry cooperation and partnerships is a must. That would result in highly professional personnel ready for the workplace. Still, more research is needed to enhance institutional perspectives and even academics on how the curriculum design and course content could be appropriately improved.

\section{Reference}

${ }^{1}$ Jalaliyoon, N. and Taherdoost, H. (2012). Performance evaluation of higher education; a necessity. Procedia- Social and Behavioral Sciences, 46, 5682-5686.

${ }^{2}$ Gleich, R., Motwani, J. and Wald, A. (2008). Process benchmarking: A new tool to improve the performance of overhead areas. Benchmarking, 15(3), 242-256.

Neely, A., Gregory, M. and Platts, K. (1995). Performance measurement system design: A literature review and research agenda. International Journal of Operations and Production Management, 15(4), 80-116.

${ }^{3}$ Craig-Smith, S. and Peiyi, D. (2007). Tourism degree education in Australia and its relevance toChina. Journal of Teaching in Travel and Tourism, 7(1), 45-61.

${ }^{4}$ Wang, J., Huyton, J., Gao, X. and Ayres, H. (2010). Evaluating undergraduate courses in tourism management: A comparison between Australia and China. Journal of Hospitality, Leisure, Sport and Tourism Education, 9(2), 4662 . 
${ }^{5}$ Du, J. (2003). Reforms and development of higher tourism education in China. Journal of Teaching in Travel \& Tourism, 3(1), 103-113.

${ }^{6}$ Afifi, G, And Abdel Wahab, S. (2010). Benchmarking the Egyptian Tourism Higher Education Scheme. An International Journal of Tourism and Hospitality Research, 21(2), 363-378.

${ }^{7}$ Kirkpatrick, D. (1959). Techniques for evaluating training programs. Journal of American Society for Training and Development, 13, 11-12, as cited in Siniscalchi, J., Beale, E. and Fortuna, A. (2008). Using ImportancePerformance Analysis to Evaluate Training. Performance Improvement, 47(10), 30-35.

Kirkpatrick, D. and Kirkpatrick, P. (2006).Evaluating training programs (3rd ed.). San Francisco: Berrett-Koehler.

${ }^{8}$ Stergioun, D. and Aireym, D. (2012). Using the Course Experience Questionnaire for evaluating undergraduate tourism management courses in Greece. Journal of Hospitality, Leisure, Sport \& Tourism Education, 11, 41-49.

${ }^{9}$ Hanbury, A.(2007). Comparative review of British. American and Australian national surveys of undergraduate students. York: Higher Education Academy, p.1.

${ }^{10}$ Horng, J., Teng, C. and Baum, T. (2013). Academic perceptions of quality and quality assurance in undergraduate hospitality, tourism and leisure programmes: A comparison of UK and Taiwanese programmes. Journal of Hospitality, Leisure, Sport \& Tourism Education, 13, 233-243.

${ }^{11}$ Gacel- Avila, J.(2005).The internationalisation of higher education: A paradigm for global citizenry. Journal of Studies in International Education, 9(2), 121-136.

${ }^{12}$ Becket and Brookes, op. cit.

${ }^{13}$ Hunter, B., White, G., and Godby, J. (2006). What does it mean to be globally competent? Journal of Studies in Higher Education, 10(3), p. 277.

${ }^{14}$ Becket, N. and Brookes, M. (2012). Developing global competencies in graduates. Journal of Hospitality, Leisure, Sport \& Tourism Education, 11, 79-82.

${ }^{15} \mathrm{Saad}$, G. (2001). Strategic performance evaluation: descriptive and prescriptive analysis. Industrial Management \& Data Systems, 101, 390-399.

${ }^{16}$ Yarmohammadian, M., Mozaffary, M. and Esfahani, S. (2011). Evaluation of quality of education in higher education based on Academic Quality Improvement Program (AQIP) Model. Procedia-Social and Behavioral Sciences, 15, 2917- 2922.

${ }^{17}$ Robbins, D. (2005). Quality assurance. In Airey, D. and Tribe, J. (Eds.), An International Handbook of Tourism Education, Oxford: Elsevier, pp. 451-468.

${ }^{18}$ Gannon, J. and Maher, A. (2011). Developing tomorrow's talent: the case of an undergraduate mentoring programme, available at: www.emeraldinsight.com/0040-0912.htm (accessed 3 March 2014).

${ }^{19}$ Toohey, S. (1999). Designing courses for higher education. Buckingham: The Society for Research into Higher Education and Open University Press.

Gomez, P., Gonzalez, M., Gil, F., Lupianez, J., Moreno, M., Rico, L. and Romero, I. (2007). Assessing the relevance of higher education courses. Evaluation and Program Planning, 30, 149-160.

${ }^{20}$ Henderson-Smart, C., Winning, T., Gerzina, T., King, S., and Hyde, S. (2006). Benchmarking learning and teaching: Developing a method. Quality Assurance in Education, 14(2), 143-155.

${ }^{21}$ Biggs, J. (1999). Teaching for quality learning at university. Buckingham: The Society for Research into Higher Education and Open University Press.

Gomez et al., op. cit.

${ }^{22}$ Siniscalchi, J., Beale, E. and Fortuna, A. (2008). Using Importance-Performance Analysis to Evaluate Training. Performance Improvement, 47(10), 30-35.

${ }^{23}$ Zaki, D. (2008). Egypt competitive advantages: introducing attribute importance and performance. Proceedings of the 26th EuroCHRIE Conference, Dubai, 11-14 October 2008.

${ }^{24}$ Siniscalchi et al., op. cit.

${ }^{25}$ Nale, A.R., Rauch, D.A., Wathen, S.A. and Barr, P.B. (2000).An exploratory look at the use of importanceperformance analysis as a curricular assessment tool in a school of business. Journal of Workplace Learning: Employee Counseling Today, 12(4), 139-145. 
${ }^{26}$ McPhillip, J. (2001). Case studies in job analysis and training evaluation. International Journal of Training and Development, 5(4), 283-289.

Nale et al., op. cit.

${ }^{27}$ Duke, C.R. (2002). Learning outcomes: Comparing student perceptions of skill level and importance. Journal of Marketing Education, 34(3), 203-217.

Nale et al., op. cit.

${ }^{28}$ Ortinau, D.J., Bush, R.P., Bush, A. and Twible, J.L. (1989). The use of importance-performance analysis for improving the quality of marketing education: Interpreting faculty-course evaluations. Journal of Marketing Education, 11(2), 78-86.

${ }^{29}$ O'Leary, S. \& Deegan, J. (2005). Ireland's destination as a tourism destination in France: attribute importance and performance. Journal of Travel Research, 43: 247-256.

${ }^{30}$ Siniscalchi et al., op. cit.

${ }^{31}$ Abou-Shouk, M., Abdelhakim, A. and Hewedi, M. (2014). Factors Affecting the Development of Target Competencies Among Final-Year Tourism and Hospitality Students in Egypt, Journal of Hospitality and Tourism Education, 26:4, 178-187.

${ }^{32}$ www.seyouf.org/ (accessed 14 April 2014).

${ }^{33}$ National Authority for Quality Assurance and Accreditation of Education (NAQAAE) (2009), Academic Standards for the Tourism and Hotels Sector, Cairo.

${ }^{34}$ www.seyouf.org/AR/plan.php?Department_ID=2\&Sublevel=\&MainLinkID=3\&SubSubLinkID=4 (accessed 4 October 2015).

${ }^{35}$ Siniscalchi et al., op. cit.

${ }^{36}$ Ibid.

${ }^{37}$ Browne, K. (2005). Snowball Sampling: Using Social Networks to Research Non-Heterosexual Women. International Journal of Social Research Methodology, 8, 47-60.

Heckathorn, D. (2002). Respondent-Driven Sampling II: Deriving Valid Population Estimates from Chain-Referral Samples of Hidden Populations. Social Problems, 49, 11-34.

${ }^{38}$ Biernacki, P. and D. Waldorf (1981). Snowball Sampling: Problems and Techniques of Chain Referral Sampling. Sociological Methods and Research, 10,141-163.

${ }^{39}$ Miller, H., Sexton, N., Koontz, L., Loomis, J., Koontz, S. and Hermans, C. (2011). The users, uses, and value of Landsat and other moderate-resolution satellite imagery in the United States- Executive report: U.S. Geological Survey Open-File Report 2011- 1031, p. 36.

${ }^{40}$ Kaiser, H. (1974). An index of factorial simplicity. Psychometrika, 39, 31-36.

Nunnally, J. (1978). Psychometric Theory. New York: McGraw-Hill.

Appendices

Appendix 1: Mean Scores of Importance and Performance of Courses Titles.

\begin{tabular}{|c|c|c|c|c|c|c|c|c|}
\hline \multirow{2}{*}{ No. } & \multicolumn{4}{|c|}{ Importance } & \multicolumn{4}{c|}{ Performance } \\
\cline { 2 - 9 } & Mean & S.D. & Ranking & $\begin{array}{c}\text { Factor } \\
\text { loading }\end{array}$ & Mean & S.D. & Ranking & $\begin{array}{c}\text { Factor } \\
\text { loading }\end{array}$ \\
\hline $\mathbf{1}$ & 4.45 & 0.64 & 2 & 0.82 & 3.84 & 0.92 & 23 & 0.61 \\
\hline $\mathbf{2}$ & 3.66 & 0.76 & 17 & 0.67 & 4.01 & 1.15 & 18 & 0.66 \\
\hline $\mathbf{3}$ & 4.45 & 0.64 & 3 & 0.81 & 3.86 & 1.22 & 21 & 0.62 \\
\hline $\mathbf{4}$ & 3.30 & 0.96 & 26 & 0.61 & 4.26 & 1.01 & 12 & 0.70 \\
\hline $\mathbf{5}$ & 3.65 & 0.48 & 22 & 0.65 & 3.73 & 1.10 & 27 & 0.58 \\
\hline $\mathbf{6}$ & 2.82 & 0.71 & 32 & 0.54 & 4.14 & 0.93 & 15 & 0.69 \\
\hline $\mathbf{7}$ & 2.61 & 1.39 & 33 & 0.52 & 3.81 & 1.22 & 25 & 0.60 \\
\hline $\mathbf{8}$ & 3.66 & 0.76 & 18 & 0.67 & 3.54 & 1.61 & 29 & 0.56 \\
\hline $\mathbf{9}$ & 4.64 & 0.99 & 1 & 0.84 & 4.03 & 1.16 & 17 & 0.66 \\
\hline $\mathbf{1 0}$ & 4.45 & 0.64 & 4 & 0.80 & 4.55 & 0.91 & 1 & 0.83 \\
\hline $\mathbf{1 1}$ & 4.32 & 0.94 & 6 & 0.78 & 4.55 & 0.91 & 2 & 0.83 \\
\hline
\end{tabular}




\begin{tabular}{|c|c|c|c|c|c|c|c|c|}
\hline $\mathbf{1 2}$ & 3.30 & 0.96 & 27 & 0.59 & 4.51 & 0.95 & 3 & 0.83 \\
\hline $\mathbf{1 3}$ & 3.30 & 0.96 & 28 & 0.59 & 3.89 & 1.05 & 20 & 0.64 \\
\hline $\mathbf{1 4}$ & 3.66 & 0.76 & 19 & 0.66 & 3.43 & 0.97 & 33 & 0.53 \\
\hline $\mathbf{1 5}$ & 4.14 & 0.45 & 12 & 0.72 & 4.27 & 1.01 & 9 & 0.78 \\
\hline $\mathbf{1 6}$ & 2.96 & 1.01 & 29 & 0.59 & 4.27 & 1.01 & 10 & 0.74 \\
\hline $\mathbf{1 7}$ & 2.95 & 1.44 & 31 & 0.57 & 3.43 & 1.12 & 34 & 0.52 \\
\hline $\mathbf{1 8}$ & 3.97 & 1.16 & 14 & 0.72 & 3.53 & 1.39 & 30 & 0.55 \\
\hline $\mathbf{1 9}$ & 4.32 & 0.94 & 7 & 0.78 & 4.35 & 1.10 & 7 & 0.80 \\
\hline $\mathbf{2 0}$ & 4.00 & 0.00 & 13 & 0.72 & 3.82 & 0.38 & 24 & 0.61 \\
\hline $\mathbf{2 1}$ & 3.31 & 0.76 & 25 & 0.61 & 3.77 & 0.73 & 26 & 0.59 \\
\hline $\mathbf{2 2}$ & 4.45 & 0.64 & 5 & 0.79 & 3.51 & 0.50 & 31 & 0.55 \\
\hline $\mathbf{2 3}$ & 3.65 & 0.48 & 23 & 0.63 & 4.35 & 0.75 & 8 & 0.79 \\
\hline $\mathbf{2 4}$ & 3.66 & 0.76 & 20 & 0.66 & 3.96 & 0.61 & 19 & 0.65 \\
\hline $\mathbf{2 5}$ & 4.32 & 0.94 & 8 & 0.75 & 4.18 & 0.90 & 13 & 0.70 \\
\hline $\mathbf{2 6}$ & 4.32 & 0.94 & 9 & 0.75 & 4.51 & 0.95 & 4 & 0.82 \\
\hline $\mathbf{2 7}$ & 2.96 & 1.01 & 30 & 0.57 & 4.18 & 0.69 & 14 & 0.69 \\
\hline $\mathbf{2 8}$ & 3.84 & 1.05 & 15 & 0.68 & 3.73 & 1.10 & 28 & 0.58 \\
\hline $\mathbf{2 9}$ & 3.43 & 1.15 & 24 & 0.62 & 4.27 & 1.01 & 11 & 0.73 \\
\hline $\mathbf{3 0}$ & 4.32 & 0.94 & 10 & 0.74 & 3.45 & 1.26 & 32 & 0.54 \\
\hline $\mathbf{3 1}$ & 4.32 & 0.94 & 11 & 0.73 & 4.42 & 0.86 & 5 & 0.81 \\
\hline $\mathbf{3 2}$ & 3.66 & 0.97 & 21 & 0.66 & 4.42 & 0.86 & 6 & 0.81 \\
\hline $\mathbf{3 3}$ & 3.84 & 0.92 & 16 & 0.68 & 3.86 & 0.88 & 22 & 0.61 \\
\hline Cronbach's & & & 0.798 & & & & \multirow{2}{*}{0.821} & \\
\hline $\mathbf{a l p h a}$ & & & & & & & \\
\hline
\end{tabular}

Appendix 2: Mean Scores of Importance and Performance of knowledge and understanding

\begin{tabular}{|c|c|c|c|c|c|c|c|c|}
\hline \multirow{2}{*}{ No. } & \multicolumn{4}{|c|}{ Importance } & \multicolumn{4}{c|}{ Performance } \\
\cline { 2 - 9 } & Mean & S.D. & Ranking & $\begin{array}{c}\text { Factor } \\
\text { loading }\end{array}$ & Mean & S.D. & Ranking & $\begin{array}{c}\text { Factor } \\
\text { loading }\end{array}$ \\
\hline $\mathbf{1}$ & 3.76 & 1.25 & 11 & 0.67 & 3.35 & 0.88 & 16 & 0.83 \\
\hline $\mathbf{2}$ & 3.92 & 1.16 & 8 & 0.71 & 4.05 & 1.01 & 11 & 0.82 \\
\hline $\mathbf{3}$ & 3.92 & 1.20 & 9 & 0.71 & 3.14 & 0.78 & 17 & 0.81 \\
\hline $\mathbf{4}$ & 4.30 & 0.93 & 3 & 0.80 & 3.46 & 0.69 & 15 & 0.78 \\
\hline $\mathbf{5}$ & 4.22 & 0.63 & 5 & 0.78 & 4.00 & 1.06 & 12 & 0.75 \\
\hline $\mathbf{6}$ & 4.22 & 0.53 & 6 & 0.75 & 4.41 & 0.86 & 5 & 0.75 \\
\hline $\mathbf{7}$ & 4.73 & 0.65 & 1 & 0.82 & 4.51 & 0.80 & 3 & 0.74 \\
\hline $\mathbf{8}$ & 4.24 & 0.86 & 4 & 0.79 & 3.68 & 0.85 & 14 & 0.71 \\
\hline $\mathbf{9}$ & 3.51 & 0.50 & 15 & 0.56 & 4.65 & 0.73 & 1 & 0.70 \\
\hline $\mathbf{1 0}$ & 3.86 & 1.22 & 10 & 0.70 & 4.30 & 0.93 & 7 & 0.69 \\
\hline $\mathbf{1 1}$ & 4.38 & 0.59 & 2 & 0.81 & 4.41 & 0.86 & 6 & 0.69 \\
\hline $\mathbf{1 2}$ & 3.96 & 1.23 & 7 & 0.73 & 3.78 & 0.85 & 13 & 0.65 \\
\hline $\mathbf{1 3}$ & 3.45 & 1.23 & 16 & 0.55 & 4.11 & 0.94 & 10 & 0.64 \\
\hline $\mathbf{1 4}$ & 3.61 & 1.08 & 12 & 0.66 & 4.24 & 0.86 & 8 & 0.60 \\
\hline $\mathbf{1 5}$ & 3.58 & 0.60 & 13 & 0.61 & 4.46 & 0.80 & 4 & 0.57 \\
\hline $\mathbf{1 6}$ & 3.55 & 1.09 & 14 & 0.60 & 4.20 & 0.89 & 9 & 0.56 \\
\hline $\mathbf{1 7}$ & 2.96 & 1.48 & 17 & 0.54 & 4.63 & 0.71 & 2 & 0.54 \\
\hline $\begin{array}{r}\text { Cronbach's } \\
\text { alpha }\end{array}$ & & \multicolumn{2}{|c|}{0.825} & & & 0.806 & \\
\hline
\end{tabular}


Appendix 3: Mean Scores of Importance and Performance of intellectual skills

\begin{tabular}{|c|c|c|c|c|c|c|c|c|}
\hline \multirow[b]{2}{*}{ No. } & \multicolumn{4}{|c|}{ Importance } & \multicolumn{4}{|c|}{ Performance } \\
\hline & Mean & S.D. & $\begin{array}{c}\text { Factor } \\
\text { loading }\end{array}$ & Ranking & Mean & S.D. & $\begin{array}{c}\text { Factor } \\
\text { loading }\end{array}$ & Ranking \\
\hline 1 & 3.74 & 1.49 & 10 & 0.57 & 3.99 & 0.82 & 6 & 0.67 \\
\hline 2 & 4.71 & 0.66 & 5 & 0.77 & 3.65 & 1.10 & 8 & 0.65 \\
\hline 3 & 4.43 & 0.77 & 6 & 0.72 & 3.64 & 0.96 & 9 & 0.54 \\
\hline 4 & 4.83 & 0.51 & 3 & 0.80 & 4.15 & 0.70 & 5 & 0.67 \\
\hline 5 & 5.00 & 0.00 & 1 & 0.82 & 4.31 & 0.76 & 2 & 0.72 \\
\hline 6 & 4.76 & 0.43 & 4 & 0.79 & 4.47 & 0.78 & 1 & 0.75 \\
\hline 7 & 4.88 & 0.48 & 2 & 0.81 & 4.16 & 0.68 & 4 & 0.68 \\
\hline 8 & 4.12 & 0.48 & 8 & 0.70 & 3.66 & 0.75 & 7 & 0.67 \\
\hline 9 & 4.27 & 0.83 & 7 & 0.71 & 3.51 & 1.11 & 10 & 0.54 \\
\hline 10 & 3.82 & 0.90 & 9 & 0.68 & 4.30 & 0.96 & 3 & 0.70 \\
\hline $\begin{array}{c}\text { Cronbach's } \\
\text { alpha }\end{array}$ & \multicolumn{4}{|c|}{0.833} & \multicolumn{4}{|c|}{0.842} \\
\hline
\end{tabular}

Appendix 4: Mean Scores of Importance and Performance of Professional Skills

\begin{tabular}{|c|c|c|c|c|c|c|c|c|}
\hline \multirow[b]{2}{*}{ No. } & \multicolumn{4}{|c|}{ Importance } & \multicolumn{4}{|c|}{ Performance } \\
\hline & Mean & S.D. & Ranking & $\begin{array}{l}\text { Factor } \\
\text { loading }\end{array}$ & Mean & S.D. & Ranking & $\begin{array}{l}\text { Factor } \\
\text { loading }\end{array}$ \\
\hline 1 & 4.32 & 0.76 & 2 & 0.82 & 3.65 & 0.96 & 10 & 0.56 \\
\hline 2 & 4.49 & 0.50 & 1 & 0.84 & 4.31 & 0.76 & 4 & 0.67 \\
\hline 3 & 3.97 & 0.83 & 5 & 0.66 & 4.32 & 0.47 & 2 & 0.70 \\
\hline 4 & 3.99 & 0.82 & 4 & 0.78 & 4.15 & 0.90 & 6 & 0.67 \\
\hline 5 & 4.00 & 0.57 & 3 & 0.80 & 4.49 & 0.50 & 1 & 0.74 \\
\hline 6 & 3.34 & 1.48 & 9 & 0.57 & 4.16 & 0.91 & 5 & 0.67 \\
\hline 7 & 3.65 & 1.25 & 7 & 0.60 & 4.32 & 0.74 & 3 & 0.68 \\
\hline 8 & 3.82 & 0.90 & 6 & 0.62 & 3.97 & 0.83 & 7 & 0.66 \\
\hline 9 & 3.15 & 1.07 & 10 & 0.53 & 3.84 & 0.68 & 8 & 0.58 \\
\hline 10 & 3.49 & 1.13 & 8 & 0.58 & 3.82 & 0.69 & 9 & 0.56 \\
\hline $\begin{array}{c}\text { Cronbach's } \\
\text { alpha } \\
\end{array}$ & \multicolumn{4}{|c|}{0.79} & \multicolumn{4}{|c|}{0.82} \\
\hline
\end{tabular}

Appendix 5: Mean Scores of Importance and Performance of General Skills

\begin{tabular}{|c|c|c|c|c|c|c|c|c|}
\hline \multirow[b]{2}{*}{ No. } & \multicolumn{4}{|c|}{ Importance } & \multicolumn{4}{|c|}{ Performance } \\
\hline & Mean & S.D. & Ranking & $\begin{array}{l}\text { Factor } \\
\text { loading }\end{array}$ & Mean & S.D. & Ranking & $\begin{array}{l}\text { Factor } \\
\text { loading }\end{array}$ \\
\hline 1 & 3.97 & 0.83 & 3 & 0.61 & 4.65 & 0.48 & 1 & 0.81 \\
\hline 2 & 3.65 & 0.75 & 5 & 0.55 & 4.49 & 0.50 & 2 & 0.79 \\
\hline 3 & 4.32 & 0.95 & 1 & 0.71 & 3.64 & 1.12 & 6 & 0.54 \\
\hline 4 & 2.36 & 1.12 & 6 & 0.54 & 4.32 & 0.95 & 3 & 0.74 \\
\hline 5 & 3.81 & 0.90 & 4 & 0.55 & 4.00 & 0.83 & 4 & 0.71 \\
\hline 6 & 3.99 & 0.59 & 2 & 0.69 & 3.66 & 1.26 & 5 & 0.69 \\
\hline $\begin{array}{c}\text { Cronbach's } \\
\text { alpha }\end{array}$ & \multicolumn{4}{|c|}{0.833} & \multicolumn{4}{|c|}{0.820} \\
\hline
\end{tabular}




\section{الملخص العربي}

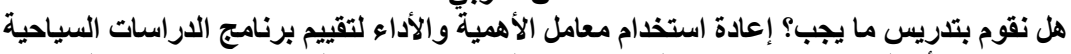

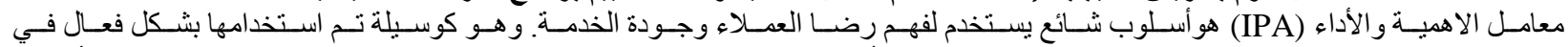

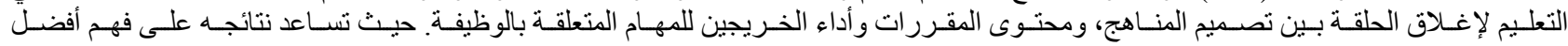

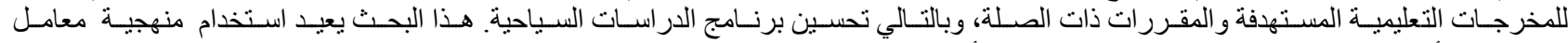

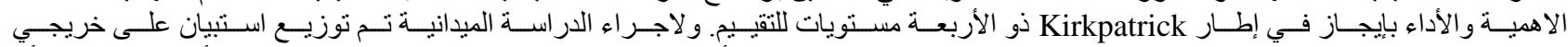

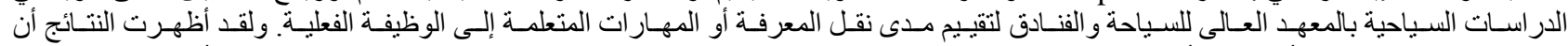

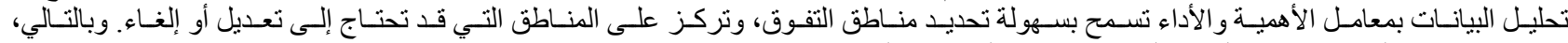

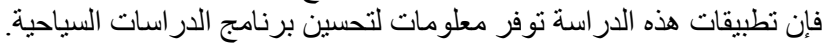

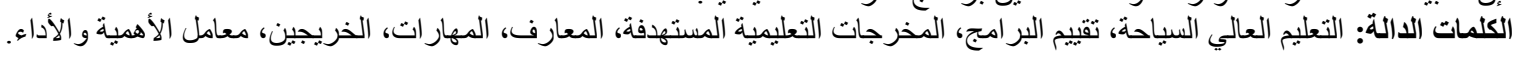

